\title{
Representation of socioscientific issues in the most popular Turkish daily newspapers ${ }^{1}$
}

\author{
Nurcan Tekin ${ }^{2}$ \\ Oktay Aslan ${ }^{3}$ \\ Suleyman Yilmaz ${ }^{4}$
}

\begin{abstract}
Socioscientific issues (SSIs) have become important in science education because of their feature of important component of scientific literacy. The purpose of this study is to analyze the representation of SSIs in Turkish national newspapers. The methodology employed in the present study is content analysis. The archives of newspapers were online searched for predetermined SSIs, news titles were categorized according to content and year. And then, samples of news tittle were selected from various newspapers for each issue tittle and were demonstrated with newspaper name and publishing year. The results demonstrated that the most mentioned SSIs are nuclear energy, environmental pollution/problems, and global warming in the last 11 years. Moreover, a steady was seen in the SSIs between 2004 and 2014. Interpretations are given in more detail in results and discussion.
\end{abstract}

Keywords: Socioscientific Issues; Newspaper Representation; Turkey.

\section{Introduction}

The importance of socioscientific issues (SSIs) in science education has received much attention and has been investigated by science education researchers in recent years. Although many scientists reached a consensus that science has influenced the society, they are aware that they do not have their role in it (Feynman, 2013). Moreover, scientific literacy has become a common internationally educational goal (The American Association for the Advancement of Science (AAAS), 1989; De Boer, 2000; Ministry of National Education of Turkey (MoNE), 2013). SSIs have become important in science education because they take part in the core of scientific literacy (Bingle and Gaskell, 1994; Dawson and Venville, 2009). In modern societies, science and technology are like a sword with two sharp side and have positive and negative outcomes (Jho, Yoon and Kim, 2014). Solutions proposed for the society, technology, and environment are considered to be a component of scientific literacy SSIs that are important components of scientific literacy and solution proposals are demanded for the encountered problems in the interaction of science with society, technology and environment. SSIs in science teaching, in the learning field of Science-Technology-Society-Environment (STTE), provide individuals to develop solution proposals and ethical and scientific reasoning skills about it (MoNE, 2013). Scientific literacy is important as it leads to the development of discussion skills, interpretation and interference (Sadler,

\footnotetext{
1 A part of the study was presented at the iSER 2015 World Conference on Education, held in Istanbul, June 10-12, 2015.

2 Res. Asst., Aksaray University, Faculty of Education, Elementary Science Education Department, tekinnurcann@gmail.com

3 Assist. Prof. Dr., Necmettin Erbakan University, Ahmet Kelesoglu Faculty of Education, Elementary Science Education Department, oktayaslan@gmail.com

4 Prof. Dr., Aksaray University, Faculty of Education, Elementary Science Education Department, yimazsuleyman@yahoo.com
} 
Tekin, N., Aslan, O., \& Yilmaz, S. (2016). Representation of socioscientific issues in the most popular Turkish daily newspapers. Journal of Human Sciences, 13(2), 2860-2869. doi:10.14687/ihs.v13i2.3779

2004; Sadler and Zeidler, 2005). Sadler (2011a) argued that as students learn science with SSIs, they would become more scientifically literate. SSIs were located in the curriculum for instructional purposes first in 2013.

Teaching social issues is highly recommended in science education to increase student understanding of economic, environmental, political, and ethical issues in science (Albe and Simonneaux, 2002, Sadler and Fowler, 2006; Sadler, 2011b). Therefore, it is required for SSI decision-makers to take notice of scientific ideas and data along with other type of knowledge (Sadler, 2009). SSIs are composed of social dilemmas with conceptual or technological links to science (Fleming, 1986; Sadler, 2004). The issues are real-world issues that are socially significant and rooted in science. Although multiple reasonable solutions exist, solutions to societal issues are not always easily explicit; (Zeidler, Walker, Ackett and Simmons, 2002). Furthermore, in the theoretical definition of "new SSIs" personal social-scientific decision-making is the initial step (Levinson, 2013). Therefore, teaching SSIs has clearly gained importance. A prominent feature of SSIs is their multidisciplinary nature (Morris, 2014). For example, Rundgren and Rundgren (2010) have developed a model called 'SEE-SEP'. This model consists of Sociology (S), Environment (E) Economy (E), Science (S), Ethics (E) and Policy (P). These issues enable interactive discussions and more. Students and teachers are acquiring such issues, at least in part, through media (Klosterman, Sadler and Brown, 2012). Students' reading and media literacy skills have a large effect on their perception of socioscientific issues, science, and finally decision-making. Students may be more effective in some areas of science; SSIs are social dilemmas that have caught the attention of national and international media sources. Individuals with media literacy might analyze issues about websites, podcasts, blogs, news articles and news reports related with SSI (Dani, Wan and Henning, 2010).

Parallel to the development of media in recent years, the SSI related problems have also increased. On the other hand, these developments have raised the concern to access true information. In the primary media literacy curriculum of MoNE, students are expected to develop a conscious and critical sland (MoNE, 2006). The aim of media literacy is to make media users aware of the socially constructed nature of media (Klosterman, Sadler and Brown, 2012).

Over the last decades, electronic media (computer, the internet, and cell phones) have become major part of daily routine (Brown and Martin, 2009). Additionally, in modern society, mass media have become increasingly significant mediators. Moreover, the progress of internet-based technologies has enhanced interest to the media (Klosterman, Sadler and Brown, 2012). With regard to analyses of media, newspapers now readily explore SSI and other science topics (Dimopoulos and Koulaidis, 2003).

According to Klosterman, Sadler and Brown (2012), secondary science teachers can use mass media reports to find SSIs and sustainability issues. However, they suggested that the use of media could put SSI based education for sustainability in order; additionally they also determined that media literacy education was limited. Dimopoulos and Koulaidis (2003) suggest that press is a useful teaching tool in terms of science and technology equipped citizenship, support decision making about social issues, and provide discussion novel conditions. According to a study of Miller in 2006 (as cited in Dani, Wan and Henning, 2010), SSIs are the target of many articles, television shows, movies, radio broadcasts, and websites. Students' media literacy skills have an extensive impact their perceptions of SSIs and science.

Media has a major contribution to the progress of individuals that they cannot realize individually. According to Turkish Statistical Institute (TSI) September 2014 data on internet usage, newspaper or magazine sites $\left(74.2^{\%}\right.$ ) rank second in online transaction. Dani, Wan and Henning (2010) state that media considers national and international sources. Therefore, the aim of this paper is to analyze to what extent SSIs were represented in the most popular Turkish national newspapers from 2004 to 2014 and how they were ranked in these newspapers. 
Tekin, N., Aslan, O., \& Yilmaz, S. (2016). Representation of socioscientific issues in the most popular Turkish daily newspapers. Journal of Human Sciences, 13(2), 2860-2869. doi:10.14687/ihs.v13i2.3779

\section{Methodology}

Qualitative research data collection methods were employed in the present descriptive study. Hence, news archives of five newspapers with accessible online archives and with the highest circulation according to November 2014 data of Newspaper Association (NA) in Turkey were online researched. The sample of the present study consist of national newspaper coverages about SSIs-related articles from January, $1^{\text {st }} 2004$ to December $31^{\text {st }}$ Data obtained via online search was subjected to content analysis. Content analysis was especially preferred as it is a technique developed to analyze the content of newspapers in the USA (Scott and Morison, 2006). Content analysis put an emphasis on speech or text and integration of specific content (Zhang and Wildemuth, 2009). According to Weber (1990) a series of procedures employed in content analysis can be made in order to make valid interference from text or speech, use. These interferences can include the senders of the message, the message, or audience of a particular message. This analysis can be used to compare media or levels of communication among individuals and groups within a certain psychological circumstance or the tendencies in the dialog content. Online content research of the newspapers determined was based on certain keywords presented in Table 1. The search outcomes yielded 92000 news with the relevant keywords. The coding schema employed is given in Table 2. For SSIs mentioned in the main headings of newspapers and news year are presented respectively in Table 3 and Figure 2. The research design was summarized in Figure 1.

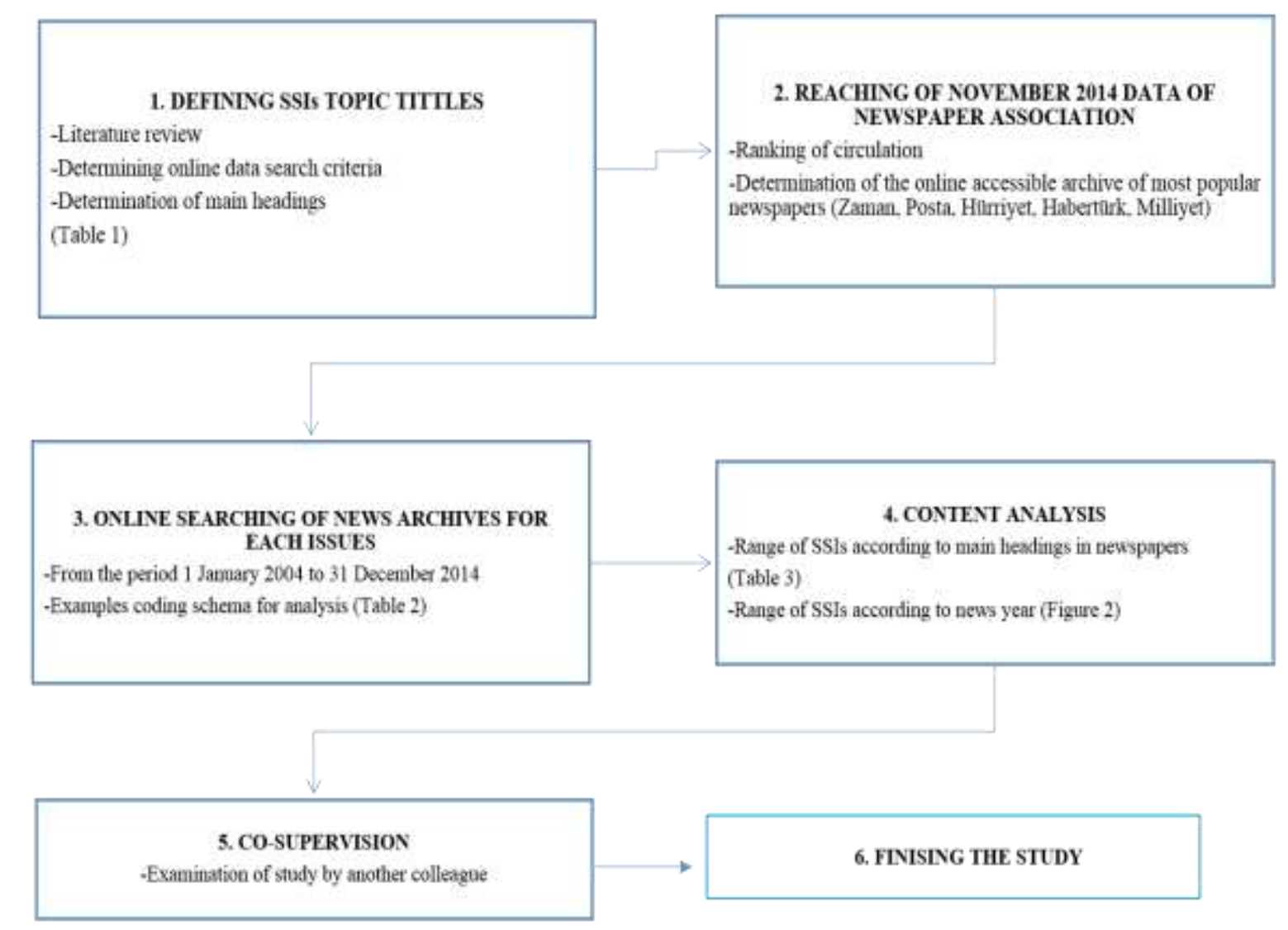

Figure 1. The research design 
Tekin, N., Aslan, O., \& Yilmaz, S. (2016). Representation of socioscientific issues in the most popular Turkish daily newspapers. Journal of Human Sciences, 13(2), 2860-2869. doi:10.14687/ihs.v13i2.3779

Table 1. Range of SSIs topics

\begin{tabular}{|c|c|c|c|}
\hline Main Heading & Issue & Code & Reference \\
\hline \multirow{7}{*}{ Biotechnology } & Stem cell & B-SCL & $\begin{array}{l}\text { Shea, 2013; Sadler, Chambers, and Zeidler, } \\
\text { 2004; Sadler and Donnelly, 2006; Levinson, } \\
\text { 2008; Reis and Galvão, 2009; Sadler and } \\
\text { Zeidler, 2005; Tal, Kali, Magid and Madhok, } \\
\text { 2011 }\end{array}$ \\
\hline & Cloning & B-CLN & $\begin{array}{l}\text { Shea, 2013; Sadler, Chambers, and Zeidler, } \\
\text { 2004; Sadler and Donnelly, 2006; Reis and } \\
\text { Galvão, 2009; Zohar and Nemet, 2002; Reis } \\
\text { and Galvão, 2004; Lee, Abd-El-Khalick and } \\
\text { Choi, 2010; Sadler and Zeidler, } 2005\end{array}$ \\
\hline & Gene therapy & B-THR & $\begin{array}{l}\text { Shea, 2013; Zohar and Nemet, 2002; Tal, } \\
\text { Kali, Magid and Madhok, } 2011\end{array}$ \\
\hline & GMO & B-GMO & $\begin{array}{l}\text { Shea, 2013; Levinson, 2008; Reis and } \\
\text { Galvão, 2004; Sadler, 2004; Lee, Abd-El- } \\
\text { Khalick and Choi, 2010; Sadler and Zeidler, } \\
\text { 2005; Tal, Kali, Magid and Madhok, } 2011\end{array}$ \\
\hline & Genetic Engineering & B-GEN & $\begin{array}{l}\text { Sadler, Chambers, and Zeidler, 2004; Sadler } \\
\text { and Donnelly, 2006; Reis and Galvão, 2004; } \\
\text { Cook, } 2012\end{array}$ \\
\hline & Genetic scanning & B-SCN & Shea, 2013; Dani, Wan and Henning, 2010 \\
\hline & Biodiversity & B-DVS & Tal, Kali, Magid and Madhok, 2011 \\
\hline \multirow{8}{*}{ Environment } & Global Warming & E-GWR & Cook, 2012; Reis and Galvão, 2009 \\
\hline & Deforestation & E-DFT & Cook, 2012; Rickinson and Lundholm, 2008 \\
\hline & Climate Change & E-CCH & Morris, 2014 \\
\hline & $\begin{array}{l}\text { Environmental } \\
\text { Pollution/Problems }\end{array}$ & E-EPP & $\begin{array}{l}\text { Cook, 2012; Acar, Turkmen and } \\
\text { Roychoudhury, 2010; Morris, 2014; Lee, } \\
\text { Abd-El-Khalick and Choi, } 2010\end{array}$ \\
\hline & $\begin{array}{l}\text { Management of Natural } \\
\text { Resources }\end{array}$ & E-MNR & Sadler, 2004 \\
\hline & $\begin{array}{l}\text { Nuclear/Radioactive } \\
\text { Wastes }\end{array}$ & E-NRW & $\begin{array}{l}\text { Morris, 2014; Lee, Abd-El-Khalick and } \\
\text { Choi, 2010; Tal, Kali, Magid and Madhok, } \\
\text { 2011 }\end{array}$ \\
\hline & Nuclear Plants & E-NUP & Rickinson and Lundholm, 2008 \\
\hline & Toxic Wastes & E-TXW & Reis and Galvão, 2004 \\
\hline Technology & Nanotechnology & T-NAN & Levinson, 2008 \\
\hline \multirow{4}{*}{ Health } & Transplantation & H-TRN & Reis and Galvão, 2004 \\
\hline & $\begin{array}{l}\text { Biological and chemical } \\
\text { weapons }\end{array}$ & $\mathrm{H}-\mathrm{BCW}$ & Dani, Wan and Henning, 2010 \\
\hline & $\begin{array}{l}\text { Smoking and using } \\
\text { alcohol }\end{array}$ & H-SUA & Acar, Turkmen and Roychoudhury, 2010 \\
\hline & Public Health & H-PHL & Reis and Galvão, 2009 \\
\hline \multirow{2}{*}{ Energy } & Nuclear Energy & E-NUE & Tal, Kali, Magid and Madhok, 2011 \\
\hline & Efficient Energy Use & E-EEU & Acar, Turkmen and Roychoudhury, 2010 \\
\hline
\end{tabular}

According to Table 1, topics studied in the SSI are biotechnology, environment, technology, health, and energy. 
Tekin, N., Aslan, O., \& Yilmaz, S. (2016). Representation of socioscientific issues in the most popular Turkish daily newspapers. Journal of Human Sciences, 13(2), 2860-2869. doi:10.14687/jhs.v13i2.3779

After literature reviews, SSIs framework for the titles were determined (i.e. stem cell, GMO, global warming, nanotechnology, nuclear energy). Then, determined tittles were collected in the main headings of 5 most circulating newspapers (biotechnology, environment, technology, health and energy). These were Zaman, Posta, Hürriyet, Habertürk and Milliyet according to 2014, November data of NA (Total circulation was taken into account). Samples of news' title were selected from various newspapers for each issue and are demonstrated with newspaper's name and publishing date in Table 2. In this stage, news' numbers were generated in each sub-category by searching topic tittles determined, during the period January 1, 2004 to December 31, 2014 (Table 3). Ultimately, news' tittles were categorized regarding years (Figure 2).

Table 2 exemplifies the SSI news in newspapers that are most popular in Turkey.

Table 2. Example coding scheme for analysis

\begin{tabular}{|c|c|c|c|}
\hline $\begin{array}{l}\text { Code of News } \\
\text { Tittle Sample }\end{array}$ & News Tittle & Newspaper & Publishing Date \\
\hline B-SCL & 404 Stem Cell Donation Done in Two Weeks & Hürriyet & 6 September 2014 \\
\hline B-CLN & $\begin{array}{l}\text { We Bring to World Three Baby by Cloning } \\
\text { Methods }\end{array}$ & Milliyet & 4 March 2009 \\
\hline B-THR & $\begin{array}{l}\text { Promising Fight Against Cancer with Modified } \\
\text { Virus Structure }\end{array}$ & Zaman & 7 July 2006 \\
\hline B-GMO & Creates Resistance the GMO to Antibiotic & Habertürk & 29 May 2014 \\
\hline B-GEN & Trying the First in Medicine & Milliyet & 30 April 2013 \\
\hline B-SCN & "The Perfect Man" Arising & Habertürk & 16 January 2013 \\
\hline B-DVS & $20 \%$ of the Flora of Turkey in Denizli & Zaman & $\begin{array}{l}29 \text { November } \\
2013\end{array}$ \\
\hline E-GWR & Tropical Storm Is Changing Direction & Habertürk & 16 May 2014 \\
\hline E-DFT & That will Prevent Erosion Plant & Posta & 23 July 2011 \\
\hline E-CCH & Flamingos of Acıöl Vanished & Hürriyet & $\begin{array}{l}15 \text { September } \\
2011\end{array}$ \\
\hline E-EPP & $\begin{array}{l}\text { When Increased Environmental Awareness, What } \\
\text { Companies are Doing? }\end{array}$ & Milliyet & 7 May 2008 \\
\hline E-MNR & Platform from Norway will Find oil in Black Sea & Zaman & 5 October 2009 \\
\hline E-NRW & $\begin{array}{l}\text { Akkuyu EIA Report Protest of Greenpeace in } \\
\text { front of Ministry of the Environment }\end{array}$ & Hürriyet & 24 July 2014 \\
\hline E-NUP & Lifeblood of Energy Investment from İstanbul & Habertürk & 18 August 2014 \\
\hline E-TXW & $\begin{array}{l}\text { A Battery Equivalent to One-Year Water of } 11 \\
\text { People }\end{array}$ & Posta & 1 April 2013 \\
\hline T-NAN & Nanotechnology lay hands on our aging & Hürriyet & 3 November 2012 \\
\hline H-TRN & 95\% Success in Organ Transplantation & Zaman & 9 November 2013 \\
\hline H-BCW & Is HIV Biological Weapons? & Hürriyet & 16 May 2008 \\
\hline H-SUA & $\begin{array}{l}\text { It is True that Drug Abuse Develop } \\
\text { Creativity...But... }\end{array}$ & Milliyet & 11 July 2014 \\
\hline H-PHL & $\begin{array}{l}\text { Ministry had Display Companies that Play with } \\
\text { People's Health }\end{array}$ & Posta & 28 October 2014 \\
\hline E-NUE & Detected a Leak in Canadian Nuclear Power Plant & Habertürk & 5 November 2013 \\
\hline E-EEU & $\begin{array}{l}\text { Domestic Using in Energy Plant Provide } 250 \\
\text { Million Liras Saving }\end{array}$ & Zaman & 28 May 2012 \\
\hline
\end{tabular}


Tekin, N., Aslan, O., \& Yilmaz, S. (2016). Representation of socioscientific issues in the most popular Turkish daily newspapers. Journal of Human Sciences, 13(2), 2860-2869. doi:10.14687/ihs.v13i2.3779

According to Table 2, “The Perfect Man Arising” (below Genetic Scanning, Habertürk Newspaper of 01.16.2013) and "Is HIV a Biological Weapon?" (below Biological and Chemical Weapons, Newspaper of Hürriyet, on 05.16.2008) were cited.

\section{Findings and Results}

Table 3 demonstrates the total number of SSIs news about according to main headings of most popular Turkish newspapers.

Table 3. Range of SSIs according to main headings in newspapers

\begin{tabular}{|c|c|c|c|c|c|c|c|c|}
\hline \multirow{2}{*}{ Main Heading } & \multirow{2}{*}{ Code } & \multicolumn{5}{|c|}{ Newspapers } & \multirow{2}{*}{$\begin{array}{c}\text { Total } \\
\text { (N) }\end{array}$} & \multirow{2}{*}{$\mathbf{P}(\%)$} \\
\hline & & Zaman & Posta & Hürriyet & Habertürk & Milliyet & & \\
\hline \multirow{7}{*}{ Biotechnology } & B-SCL & 742 & 271 & 1191 & 469 & 670 & 3343 & 3,63 \\
\hline & B-CLN & 228 & 31 & 228 & 83 & 118 & 688 & 0,75 \\
\hline & B-THR & 28 & 4 & 53 & 13 & 26 & 124 & 0,13 \\
\hline & B-GMO & 455 & 62 & 1458 & 215 & 349 & 2539 & 2,75 \\
\hline & B-GEN & 255 & 38 & 198 & 50 & 128 & 669 & 0,73 \\
\hline & B-SCN & 91 & 13 & 203 & 120 & 160 & 587 & 0,64 \\
\hline & B-DVS & 122 & 9 & 98 & 17 & 41 & 287 & 0,31 \\
\hline \multirow{8}{*}{ Environment } & E-GWR & 3793 & 55 & 2311 & 627 & 1470 & 8256 & 8,96 \\
\hline & E-DFT & 12 & 1113 & 5 & 15 & 9 & 1154 & 1,25 \\
\hline & E-CCH & 3067 & 214 & 1638 & 472 & 1269 & 6660 & 7,22 \\
\hline & E-EPP & 5300 & 265 & 1654 & 387 & 936 & 8542 & 9,27 \\
\hline & E-MNR & 1800 & 52 & 100 & 653 & 65 & 2670 & 2,90 \\
\hline & E-NRW & 370 & 2 & 101 & 15 & 57 & 545 & 0,60 \\
\hline & E-NUP & - & 35 & 1759 & 112 & 203 & 2109 & 2,29 \\
\hline & E-TXW & 2991 & 151 & 125 & 22 & 83 & 3372 & 3,66 \\
\hline Technology & T-NAN & 563 & 52 & 449 & 143 & 268 & 1475 & 1,60 \\
\hline \multirow{4}{*}{ Health } & H-TRN & 335 & 77 & 2268 & 929 & 1377 & 4986 & 5,41 \\
\hline & $\mathrm{H}-\mathrm{BCW}$ & 2146 & 425 & 329 & 211 & 303 & 3414 & 3,70 \\
\hline & H-SUA & 2600 & 69 & 1208 & 762 & 874 & 5513 & 5,98 \\
\hline & H-PHL & 964 & 13 & 2668 & 1399 & 1744 & 6788 & 7,36 \\
\hline \multirow{2}{*}{ Energy } & E-NUE & 15146 & 52 & 3699 & 1348 & 2540 & 22785 & 24,72 \\
\hline & E-EEU & 5168 & 2 & 268 & 81 & 159 & 5678 & 6,16 \\
\hline
\end{tabular}

N: Number of news

According to Table 3, between 2004-2014, the most emphasized SSIs in the newspapers are "nuclear energy" 22785 (24.72\%), followed with below the category of energy, "environmental pollution/problems" $8542(9.27 \%)$, below the category of environment and "global warming" 8256 $(8.96 \%)$ below the category of environment; fewest emphasized ones are "Gene therapy" 124 $(0.13 \%)$ and "Biodiversity" $287(0.31 \%)$ below the category of biotechnology and subsequent to "nuclear/radioactive wastes" $545(0.60 \%)$ are among the less common categories within these 5 years. Figure 2 illustrates the total number of the most popular SSI news in Turkey distributed according to the years (Number of news shown in parentheses and atop the relevant year). 
Tekin, N., Aslan, O., \& Yilmaz, S. (2016). Representation of socioscientific issues in the most popular Turkish daily newspapers. Journal of Human Sciences, 13(2), 2860-2869. doi:10.14687/jhs.v13i2.3779

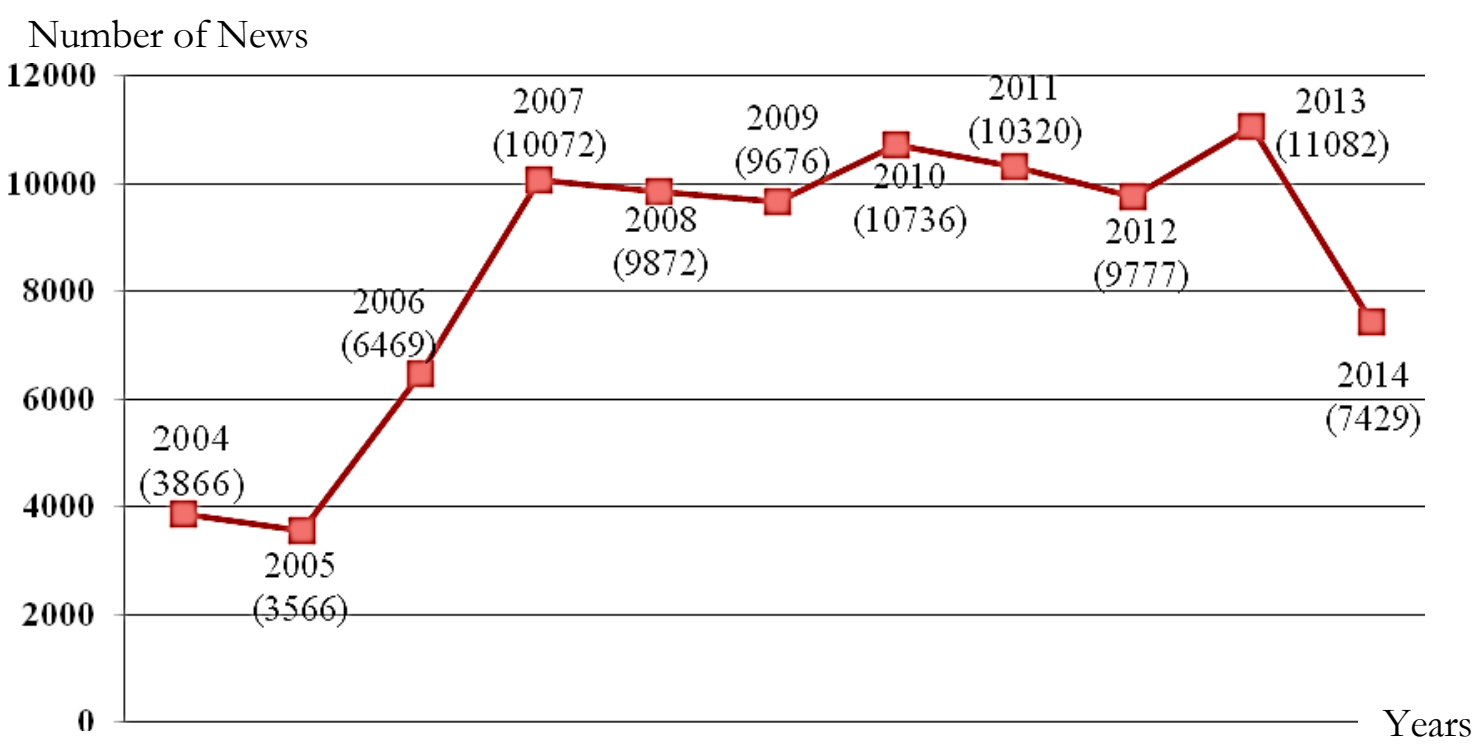

Figure 2. Range of SSIs according to years

According to Figure 2, SSIs in the newspapers are mentioned the most in $201311082(11.93 \%)$ and the fewest in 20053566 (3.84\%).

\section{Discussion}

The results from this study show that the most popular five Turkish daily newspapers about representation of SSIs according to issues and news year in recent 11 years in Turkey.

\section{The Representation of SSIs in the Most Popular Turkish Newspapers according to Issues}

In the last 11 years, the most emphasized socioscientific issues are nuclear energy, environmental pollution/problems and global warming in the five most popular Turkish newspapers. These issues, highlight the focus on environment and energy. In Poberezhskaya's (2015) study about climate change, out increase of articles from Kyoto Conference of 1997 to Copenhagen Conference are presented. As the issues within the government policy and thus under public notice, they will inevitably find their place in in the media. For this reason, problems frequently faced by the people in everyday life will find easily their place in the newspapers. Krosnick, Holbrook and Visser (2000) state that although there was an increase attitude to global warming and reports in the media, global warming as a national problem did not change. Besides the impact of global warming on people and on other species, the awareness among people is unavoidable. With respect to nuclear energy, Kim (2014) suggests that after the 2000s and particularly after the Fukushima incident, in the newspapers, environmental activists paid attention socially but media or civil organizations locally did not receive any attention. The impact of adverse conditions of nuclear energy plant in enclosed areas have been considered in last few decades in Turkey. For example, the effects of the Chernobyl Reactor Incident had an impact in north zones of our country. On the other hand in the most popular Turkish newspapers, the least reported SSIs are gene therapy, biodiversity and nuclear/radioactive wastes. These issues were paid less attention compared to environmental and energy issues. This may be because of the problems faced in everyday life.

\section{The Representation of SSIs in the Most Popular Turkish Newspapers according to the Years}

In the last 11 years, SSIs took most part in 2013 and the least in 2005. However, there was between these years a steadily rising increase in SSIs. Due to social, ethical and argumentative feature of SSIs, they have come more and more into prominence. Especially, because of the direct relationship of SSIs to people's life, representation of these issues have increasingly become linked to characteristic features of these issues. According to results of Teräväinen's (2014) study about 
Tekin, N., Aslan, O., \& Yilmaz, S. (2016). Representation of socioscientific issues in the most popular Turkish daily newspapers. Journal of Human Sciences, 13(2), 2860-2869. doi:10.14687/ihs.v13i2.3779

representation of energy policy and technology in the British and Finnish newspapers, in both countries energy technologies have increasingly linked to societal and political questions. In developing countries such as Turkey, energy requirements have found their place in the agenda. In line with the Energy Strategy of Republic of Turkey Ministry of Foreign Affairs, the limits of Turkey's domestic energy sources in light of its growing energy demand have led to dependency on energy imports. In order to reduce energy dependence, Turkey has already signed an agreement concerning the construction and operation of a nuclear power plant in 2010 (Republic of Turkey Ministry of Foreign Affairs, 2015). The Eighth-Ninth Five-Year Development Plan steered the policy towards integrated sustainable development. Within the same years, within the EU harmonization process, emphasis of Turkey to international environmental commitment has increased (Sustainable Development Report of Turkey, 2012, p.31).

The present study draws attention to the sharp decline of SSIs in 2014. This decrease may be attributed to the presidential news which have had wide media coverages in the country's agenda in 2014 According to TSI (2015), in 2014 political news have had the highest rate (85.8\%). Otherwise, in 2014 compared to previous four years newspaper circulation has decreased. This can be attributed to the decrease in the total news number.

\section{Conclusion}

It is concluded that environment and energy related socioscientific issues are frequently reported in the most popular Turkish daily newspapers. Because of energy usage and consumption agenda of Turkey leaded to environmental arguments are drawn a great deal of attention by society, it provide that these issues become important.

Otherwise, there was a steadily rising increase in socioscientific issue related news in the last 11 years. This increasing show that SSIs are paid attention by both columnist or newspapermen and society.

In this case, students and educators should be closely interested in many media devices such as newspaper, book, magazine, video, and internet. In the analysis of the messages transferred through the media, society-media connection should describe the effects of SSIs.

\section{References}

AAAS (The American Association for the Advancement of Science). (1989). Science for All Americans. Washington DC: AAAS.

Acar, O., Turkmen, L., and Roychoudhury, A. (2010) Student difficulties in socio-scientific argumentation and decision-making research findings: Crossing the borders of two research lines, International Journal of Science Education, 32 (9), 1191-1206.

Aikenhead, G. S. (1994). What is the STS science teaching? In Solomon, J. And Aikenhead, G. (Eds.) STS education: International perspectives on reform (New York: Teachers College), 47-59.

Albe, V. and Simonneaux, L. (2002). Teaching socio-scientific issues in classroom. Paper presented at the Annual Meeting of the North American Association for Research in Science Teaching, New Orleans.

Bingle,W. H., and Gaskell, P. J. (1994). Scientific literacy for decisionmaking and the social construction of scientific knowledge. Science Education, 78(2), 185- 201.

Brown, B., and Marin, P. (2009). Adolescents and electronic media: growing up plugged in. Retrieved from www.childtrends.org

Cook, K. L. (2012). Can we really make a difference? Exploring pre-service teachers' experience with socio-scientific issues aiming for democratic participation in science. Doctor of Philosophy Thesis, Indiana University, Indiana.

Dani, D., Wan, G., and Henning, J. E. (2010). A case for media literacy in the context of socioscientific issues. New Horizons in Education, 58 (3), 85-98. 
Tekin, N., Aslan, O., \& Yilmaz, S. (2016). Representation of socioscientific issues in the most popular Turkish daily newspapers. Journal of Human Sciences, 13(2), 2860-2869. doi:10.14687/ihs.v13i2.3779

Dawson, V., and Venville, G. J. (2009). High-school students' informal reasoning and argumentation about biotechnology: An indicator of scientific literacy? International Journal of Science Education, 3 (11), 1421-1445.

DeBoer, G. E. (2000). Scientific literacy: Another look at its historical and contemporary meanings and its relationship to science education reform. Journal of Research in Science Teaching, 37(6), 582-601.

Dimopoulos, K., and Koulaidis, V. (2003). Science and technology education for citizenship: The potential role of the press. Science Education, 87(2), 241-256.

Feynman, R. P. (2013). Başkalarmm Ne Düşündïgünden Sana Ne? (Lale Aykent Tunçman and Tuna Aykent Tunçman, Trans.). İstanbul: Alfa.

Fleming, R. (1986). Adolescent reasoning in socio-scientific issues, part I: social cognition. Journal of Research in Science Teaching, 23 (8), 677-687.

Jho, H., Yoon, H. G., and Kim, M. (2014). The relationship of science knowledge, attitude and decision making on socio-scientific issues: The case study of students' debates on a nuclear power plant in Korea. Science and Education, 23, 1131-1151.

Kim, H. (2014). Reconstructing the public in old and new governance: A Jorean case of nuclear energy policy. Public Understanding of Science, 23 (3), 268-282.

Klosterman, M. L., Sadler, T. D., and Brown, J. (2012). Science teachers' use of mass media to address socio-scientific and sustainability issues. Research in Science Education, 42, 51-74.

Krosnick, J. A., Holbrook, A. L., and Visser, P. S. (2000). The impact of the fall 1997 debate about global warming on American public opinion. Public Understanding of Science, 9, 239-260.

Lee, H., Abd-El-Khalick, F., and Choi, K. (2006). Korean science teachers' perceptions of the introduction of socio-scientific issues into the science curriculum, Canadian Journal of Science, Mathematics and Technology Education, 6(2), 97-117.

Levinson, R. (2013). Practice and theory of socio-scientific issues: An authentic model? Studies in Science Education, 49 (1), 99-116.

Levinson, R. (2008). Promoting the role of the personal narrative in teaching controversial socioscientific issues. Science and Education, 17, 855-871.

MoNE (Ministry of National Education of Turkey) (2013). İlkögretim Kurumlarn Fen Bilimleri Dersi Ögretim Programı. Ankara: Milli Eğitim Bakanlığı Talim ve Terbiye Kurulu Başkanllğı.

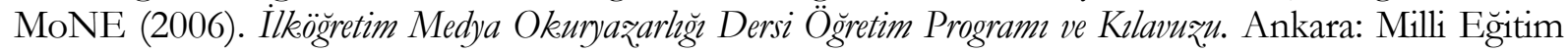
Bakanlı̆̆ Talim ve Terbiye Kurulu Başkanlığı.

Morris, H. (2014). Socioscientific issues and multidisiplinarity in school science textbooks. International Journal of Science Education, 36 (7), 1137-1158.

Poberezhskaya, M. (2015). Media coverage of climate change in Russia: Governmental bias and climate silence. Public Understanding of Science, 24 (1), 96-111.

Reis, P., and Galvão, C. (2009). Teaching controversial socio-scientific issues in biology and geology classes: A case study. Electronic Journal of Science Education, 13 (1), 1-24.

Reis, P. and Galvão, C. (2004). The impact of socio-scientific controversies in Portuguese natural science teachers' conceptions and practices. Research in Science Education, 34, 153-171.

Republic of Turkey Ministry of Foreign Affairs. (2015). Retrived April, 23, 2015 from http://www.mfa.gov.tr/turkeys-energy-strategy.en.mfa

Rickinson, M., and Lundholm, C. (2008). Exploring students' learning challenges in environmental education. Cambridge Journal of Education. 38 (3), 341-353.

Rundgren, S. C., and Rundgren, C. J. (2010). SEE-SEP: From a seperate to holisti view of socioscientific issues. Asia-Pacific Forum on Science Learning and Teaching, 11 (1), 1-24.

Sadler, T. D. (2011a). Socio-scientific issues-based education: What we know about science education in the context of SSI. T. D. Sadler (Ed). Socio-scientific Issues in the Classroom: Teaching, Learning and Research (pp. 355-369). New York: Springer. 
Tekin, N., Aslan, O., \& Yilmaz, S. (2016). Representation of socioscientific issues in the most popular Turkish daily newspapers. Journal of Human Sciences, 13(2), 2860-2869. doi:10.14687/ihs.v13i2.3779

Sadler, T. D. (2011b). Situating socio-scientific issues in classrooms as a means of achieving goals of science education. T. D. Sadler (Ed). Socio-scientific Issues in the Classroom: Teaching, Learning and Research (pp. 1-10). New York: Springer.

Sadler, T. D. (2009). Situated learning in science education: Socio-scientific issues as contexts for practice. Studies in Science Education, 45(1), 1-42.

Sadler, T. D. (2004). Informal reasoning regarding socioscientific issues: A critical review of research. Journal of Research in Science Teaching, 41 (5), 513-536.

Sadler, T. D., Chambers, F. W., and Zeidler, D. L. (2004). Student conceptualizations of the nature of science in response to a socioscientific issue. International Journal of Science Education, 26, $387-$ 409.

Sadler, T. D., and Donnelly, L. A. (2006). Socioscientific argumentation: The effects of content knowledge and morality. International Journal of Science Education, 28 (12), 1463-1488

Sadler, T. D., and Fowler, S. (2006). A threshold model of content knowledge transfer for socioscientific argumentation. Science Education, 90, 986-1004.

Sadler, T. D., and Zeidler D. L. (2005). Patterns of informal reasoning in the context of socioscientific decision making. Journal of Research in Science Teaching, 42 (1), 112-138.

Scott, D., and Morrison, M. (2006). Key Ideas in Educational Research. New York: Continuum.

Shea, N. A. (2013). Investigation the role of content knowledge, argumentation, and situational features to support genetics literacy. Doctor of Philosophy Dissertation, The State University of New Jersey, New Jersey.

Sustainable Development Report of Turkey (2012). Sustainable Development in Turkey: Have the Future (Report No. 1). Ankara: Ministry of Development.

Tal, T., Kali, Y., Magid, S., and Madhok, J. J. (2011). Enhancing the authenticity of a web-based module for teaching simple inheritance. T. D. Sadler (Ed). Socio-scientific Issues in the Classroom: Teaching, Learning and Research (pp. 11-38). New York: Springer.

Teräväinen, T. (2014). Representation of energy policy and technology in British and Finnish newspaper media: A comparative perspective. Public Understanding of Science, 23 (3), 299-315.

Turkish Statistical Institute (2015). Retrieved October 15, 2015 from http://www.tuik.gov.tr/PreHaberBultenleri.do?id=18523

Weber, R. P. (1990). Basic Content Analysis (2 ${ }^{\text {nd }}$ Ed.). California: SAGE.

Zeidler, D., Walker, K., Ackett, W., and Simmons, M. (2002). Tangled up in views: Beliefs in the nature ofscience and responses to socioscientific dilemmas. Science Education, 86(3), 343-367.

Zhang, Y., and Wildemuth, B. M. (2009). Qualitative analysis of content. B. M. Wildemuth (Ed.). Applications of Social Research Methods to Questions in Information and Library Science (pp. 308-319). Westport, CT: Libraries Unlimited.

Zohar, A., and Nemet, F. (2002). Fostering students' knowledge and argumentation skills through dilemmas in human genetics. Journal of Research in Science Teaching, 39, 35-62. 